\title{
Perancangan Dan Penataan Penerangan Jalan Umum Dengan Aplikasi Dialux evo 8.2 Di Jalan Depok Cilodong
}

\author{
Juara Mangapul Tambunan'; Albert Gifson Hutajulu²; Hendrianto Husada ${ }^{3}$ \\ ${ }^{1,2,3}$ Dosen Tetap Fakultas Ketenagalistrikan dan Energi Terbarukan, Institut Teknologi PLN \\ 1 juara.mangapul@itpln.ac.id
}

\begin{abstract}
Public street lighting has become a necessity for many people, which is very important for twowheeled, four-wheeled, and many-wheeled drivers for safety and comfort in traffic, especially at night. Therefore, the authors conducted a new research design by arranging public street lighting in the area of the Depok Cilodong highway, with the aim of providing the beauty of the road environment by the model of the arrangement and installation of poles, pole height and PJU lamp models to the road body. Its uniqueness is seen from the perspective of the side of social and environmental impacts that are generally not seen by the local government and the level of evenness of road lighting on road materials is still lacking, so that the impact on the road user community is better and more modern. The method used with the Dialux EVO 8.2 Program for short road lengths can choose street lights taken from the IES Lighting data on the 10W Eco Led, 10 VAC Milky Way, which is installed with a height of 8 meters with a distance between poles 15 meters with a large amount of procurement allows for high costs. For the long distance of, you can use the 20W, 10 VAC, which is installed with a height of 8 meters and 20 meters between the poles. So by analyzing the selection criteria, it is capable of producing street lighting in accordance with SNI 7391-2008 and considering the tipping point which has an impact on financing for installation services.
\end{abstract}

Keywords: Public Street Lighting, IES Lighting, Led Bimasakti, Dialux evo 8.2

\begin{abstract}
ABSTRAK
Penerangan Jalan Umum menjadi suatu kebutuhan masyarakat banyak yang sangat penting bagi pengendara roda dua, roda empat, dan roda banyak untuk keamanan dan kenyamanan dalam berlalu lintas, terutama malam hari. Oleh karena itu, penulis melakukan rancangan penelitian yang baru dengan menata Lampu Penerangan Jalan umum wilayah di kawasan jalan raya Depok Cilodong, dengan tujuan memberi keindahan lingkungan jalan dengan model penataan dan pemasangan tiang, tinggi tiang dan model lampu PJU terhadap badan jalan. Keunikannya dilihat dari sudut pandang sisi dampak sosial lingkungan yang secara umum tidak dilihat oleh pemerintah daerah setempat dan kemerataan tingkat pencahayaan jalan terhadap material jalan masih sangat kurang, sehingga dampaknya terhadap masyarakat pengguna jalan menjadi lebih baik dan modern. Metode yang dipakai dengan Program Dialux evo 8.2 untuk panjang jalan yang jaraknya pendek bisa memilih lampu jalan yang diambil dari data IES Lighting pada Led Bimasakti Eco 10W, 10 $V A C$, yang dipasang dengan tinggi tiang 8 meter dengan jarak antar tiang 15 meter dengan banyaknya pengadaan yang memungkinkan timbulnya biaya cost yang tinggi. Untuk jarak yang jauh, bisa menggunakan lampu jalan 20W, 10 VAC, dimana dipasang dengan tinggi tiang 8 meter dan jarak antar tiang 20 meter. Maka dengan analisa kriteria pemilihan tersebut mampu menghasilkan pemasangan lampu jalan yang telah sesuai SNI 7391-2008 dan mempertimbangkan titik pasang yang berdampak pada pembiayaan terhadap jasa Pemasangan
\end{abstract}

Kata kunci: Penerangan Jalan Umum, IES Lighting, Led Bimasakti, Dialux evo 8.2 


\section{Energi dan Kelistrikan: Jurnal Ilmiah}

Vol. 12, No. 2, Juli - Desember 2020, P-ISSN 1979-0783, E-ISSN 2655-5042

https://doi.org/10.33322/energi.v12i2.982

\section{PENDAHULUAN}

Penerangan Jalan Umum merupakan layanan publik yang penting yang dapat mempengaruhi tingkat aktivitas manusia dalam memberi keselamatan bagi pengendara dan pejalan kaki. Fenomenafenomena inilah yang akan menimbulkan terjadinya dampak negatif dari kurang optimalnya pencahayaan dari lampu penerangan jalan umum yang dihasilkan. Timbulnya dampak negatif, seperti tindak kriminal/kejahatan, bertambahnya angka kecelakaan yang terjadi, dan gangguan kesehatan pada mata. Dengan demikian, Penerangan Jalan Umum perlu ditata sedemikian rupa baik dilihat dari jenis tiang, lampu dan warna lampu yang beraneka macam dengan badan jalan yang mempengaruhinya dan juga dapat dilihat dari segi keindahan (estetika). Kondisi PJU sebagian besar belum sesuai standard dan belum menggunakan alat pencatat dan pembatas listrik [7]. Lampu-lampu yang dipakai masih banyak yang menggunakan lampu dengan konsumsi daya tinggi tetapi lumen rendah. Masih banyak kondisi PJU yang padam dan liar tidak tercatat pemakaian dayanya. Penggunaan lampu jalan menggunakan lampu LED dengan lampu konvensional secara teknis dan ekonomis energi menjadi solusi yang dapat menyelesaikan permasalahan tagihan listrik yang terus bertambah seiring dengan kenaikan tarif dasar listrik dan kebutuhan pemasangan PJU bagi wilayah dengan tingkat urbanisasi penduduk yang tinggi [5][12]. Demikian juga, penggunaan lampu penerangan jalan umum dengan jenis lampu jalan pintar dengan sistem embedded telah dilengkapi dengan pengatur sistem penerangan (dimmer system) dan kontroler untuk menyalakan dan juga mematikan sistem secara otomatis berdasarkan intensitas cahaya dan aktivitas disekitarnya, sehingga aliran listrik dapat disesuaikan dengan kebutuhan penerangan jalan [6]. Sistem perancangan dan penataan ini diharapkan dapat mendukung sistem lampu jalan pintar dan dapat lebih handal, efisien, serta mudah dalam perawatannya. Dengan perangkat Dialux evo 8.2 inilah model tampilan perancangan dan penataan LPJU wilayah Cilodong dapat diperbarui model trotoar, jenis tiang dan tinggi tiang yang sesuai dengan kondisi area lebar jalan dan perkembangan pembangunan kota Cilodong saat ini.

\section{METODE/PERANCANGAN PENELITIAN}

Metode yang dipakai dalam melakukan observasi penelitian ini adalah dengan menggunakan metode kuantitatif. Pemilihannya berdasarkan data hasil pengukuran dan observasi lapangan dengan melihat kondisi area jalan raya Depok Cilodong dan kondisi badan jalan, karena data yang di dapat merupakan nilai real dari hasil pengamatan dan pengukuran, survey lapangan dengan suku dinas PJU bersama Asosiasi Iluminasi Lighting Society (ILS) dan Himpunan Teknik Iluminasi Indonesia (HTII) yang terkait. Pengumpulan data dilakukan dengan penempatan, penataan dan pengukuran Lampu PJU. Metode dalam penelitian ini akan menghasilkan model perancangan penataan lampu jalan umum (LPJU) dengan menggunakan aplikasi perancangan Dialux evo 8.2 dengan mengolah data dan beberapa desain lampu jalan umum pintar dengan IES File.

Dengan menentukan letak lokasi dan survey lapangan serta kebutuhan material yang diperlukan, identifikasi masalah, fungsi dan tujuan dalam perancangan dan penataan lampu LPJU serta sumber data-data IES File berdasar spesifikasi teknis dan penentuan dan peletakan lampu, yang kemudian data-data dilakukan dengan pengukuran dan pengujian, di olah menggunakan setting program Dialux evo 8.2, yang selanjutnya di analisa dan diperbandingkan apakah telah sesuai dengan standar SNI yang diharapkan. Berikut tahapan metodologi penelitian yang menjelaskan alur (flowchart) perancangan penelitian [11]. 


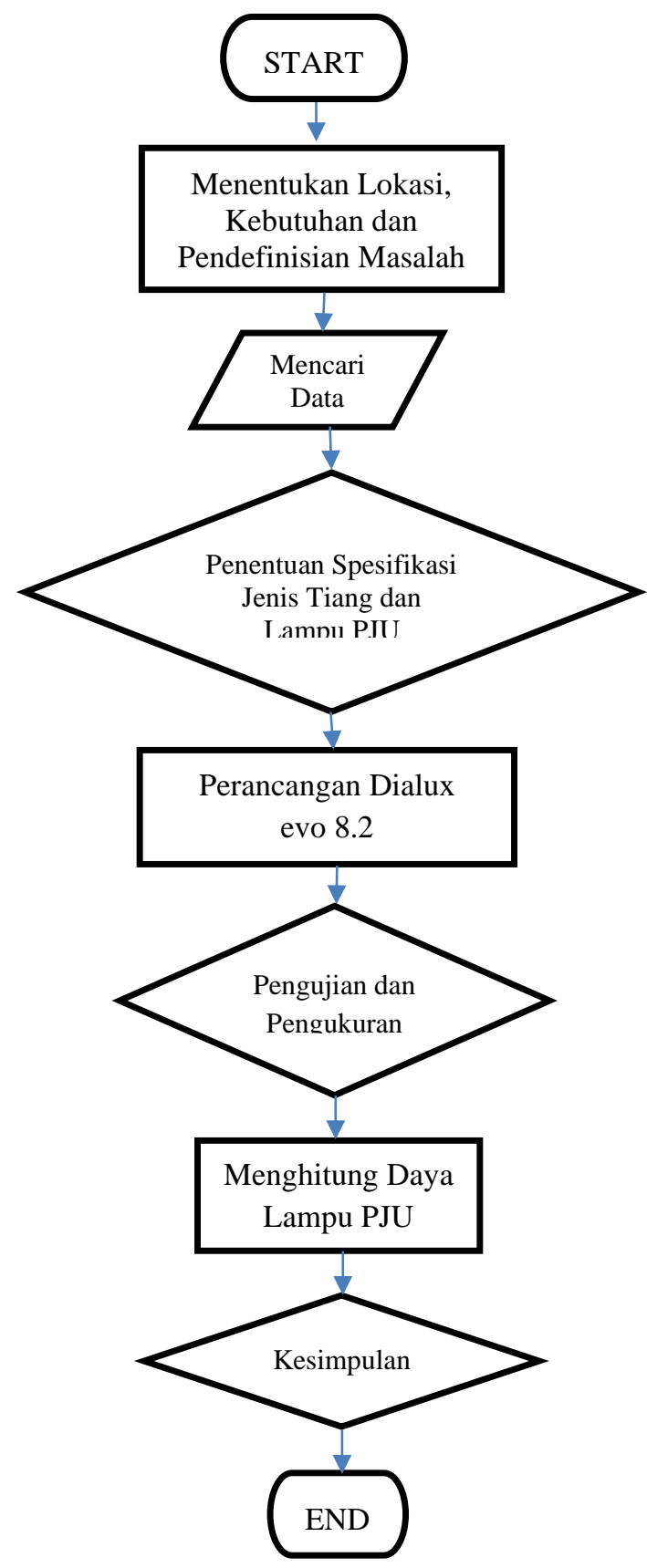

Gambar 1. Flowchart Perancangan

\section{HASIL DAN PEMBAHASAN}

Jenis lampu Bimasakti yang dipakai adalah $40 \%$ produk dari kandungan lokal dalam negri dan yang unik disini adalah lensa, chip, dan driver di mana housing dari lampu terlihat lebih awet dan kuat. Pada gambar 2 menunjukkan data spesifikasi umum Bimasakti Eco 10W, 20W, dengan power factor 0,97 , THD $<10 \%$, efficacy $>85 \mathrm{Lm} / \mathrm{W}$, dan material housing Cast Alumunium. Sedangkan gambar 3 menunjukkan disain perancangan LPJU dengan lebar jalan 5meter dan gambar 4 memperlihatkan disain perancangan LPJU untuk lebar jalan 6 meter. Spesifikasi Data Teknis dari jenis lampu yang digunakan pada gambar 2, adalah sebagai berikut: 


\section{Energi dan Kelistrikan: Jurnal Ilmiah}

Vol. 12, No. 2, Juli - Desember 2020, P-ISSN 1979-0783, E-ISSN 2655-5042

https://doi.org/10.33322/energi.v12i2.982

Spesifikasi Umum / General Specification

\begin{tabular}{|c|c|c|}
\hline Kode Produksi / Code Product & 341711352470 & 341711352580 \\
\hline Konsumsi Daya / Power Consumption (Watt) & $10 \mathrm{~W}$ & $20 \mathrm{~W}$ \\
\hline Tegangan / Voltage & \multicolumn{2}{|c|}{$220-240 \mathrm{~V}$} \\
\hline Frekuensi / Frequency & \multicolumn{2}{|c|}{$50 \mathrm{~Hz}$} \\
\hline Faktor Daya / Power Factor & \multicolumn{2}{|c|}{0,97} \\
\hline THO & \multicolumn{2}{|c|}{$<10 \%$} \\
\hline CCT (Kelvin) & \multicolumn{2}{|c|}{$4000-6000 \mathrm{~K}$} \\
\hline Efikasi / Efficacy & \multicolumn{2}{|c|}{$>85 \mathrm{Im} / \mathrm{W}$} \\
\hline CRI (Ra) & \multicolumn{2}{|c|}{$>70 \mathrm{Ra}$} \\
\hline Tingkat Proteksi / Index Protection (IP) & \multicolumn{2}{|c|}{ IP66 } \\
\hline Suhu Operasi / Operating Temperature & \multicolumn{2}{|c|}{$<5^{\circ} \mathrm{C} \sim+55^{\circ} \mathrm{C}$} \\
\hline Material Housing & \multicolumn{2}{|c|}{ Die Cast Alumunium } \\
\hline Usia Nyala Lampu / Life Time & \multicolumn{2}{|c|}{$50.000 \mathrm{jam} / 50.000$ hours } \\
\hline Garansi / Warranty & \multicolumn{2}{|c|}{5 (lima) Tahun / 5 (Five) Years } \\
\hline Berat Produk / Weight of Product & \multicolumn{2}{|c|}{$\approx 1.3 \mathrm{Kg}$} \\
\hline Dimensi Produk / Dimension of Product & \multicolumn{2}{|c|}{$495 \times 210 \times 64 \mathrm{~mm}$} \\
\hline Pole Diameter & \multicolumn{2}{|c|}{036.40} \\
\hline
\end{tabular}

Gambar 2. Spesifikasi Umum Bimasakti Eco 10W, 20W

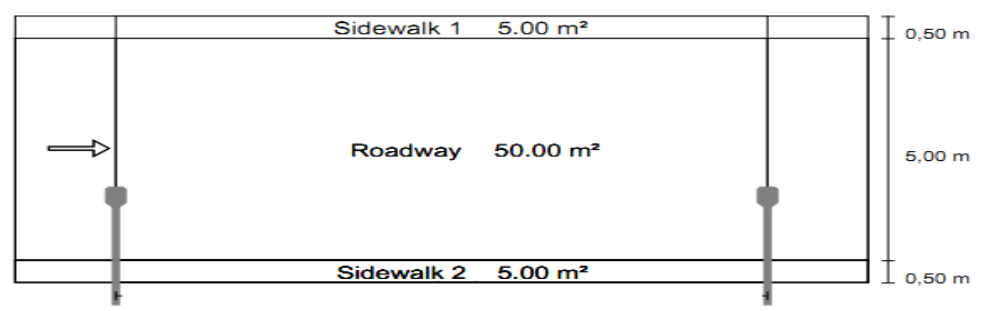

Gambar 3. Roadway Perancangan dan Pemantauan LPJU dengan Lebar Jalan 5 meter [8]

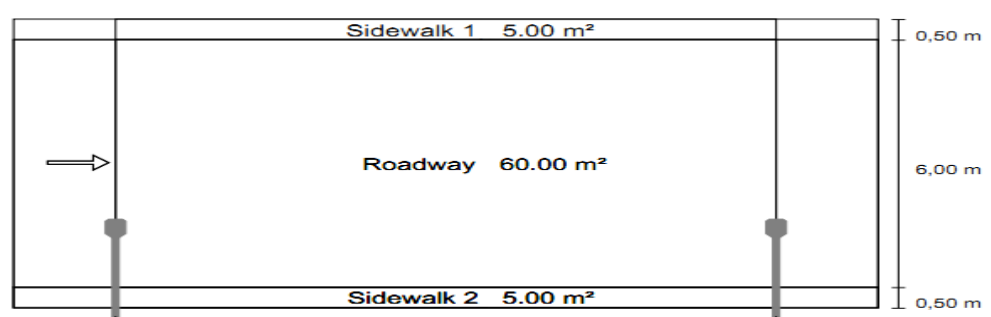

Gambar 4. Roadway Perancangan dan Pemantauan LPJU dengan Lebar Jalan 6 meter[8]

Tabel 1. Tipe Lampu Jalan Dengan Standar Kualitas Pencahayaan SNI 7391:2008

\begin{tabular}{|c|c|c|c|c|c|c|c|c|}
\hline \multicolumn{9}{|c|}{ Tipe Lampu Mengacu Standar Kualitas Pencahayaan (SNI 7391 : 2008) } \\
\hline \multirow[b]{2}{*}{ Tipe lampu jalan } & \multicolumn{8}{|c|}{ Kualitas Pencahayaan Standard SNI 》 Jenis Jalan ; Lokal Primer / Sekunder dan trotoar standar } \\
\hline & $\begin{array}{c}\text { Pencahayaan jalan } \\
-E(\text { Lux })\end{array}$ & $\begin{array}{l}\text { Lumen rata-rata } \\
\text { jalan }(\mathrm{L}=\mathrm{Cd} / \mathrm{m} 2)\end{array}$ & $\begin{array}{l}\text { Pencahayaan - } \\
\text { trotoar E (Lux) }\end{array}$ & $\begin{array}{c}\text { Lumen rata-rata } \\
\text { trotoar }(\mathrm{L}= \\
\mathrm{Cd} / \mathrm{m} 2)\end{array}$ & $\begin{array}{c}\text { Uniformity - } \mathrm{g} 1= \\
\text { Emin/Emax }\end{array}$ & $\begin{array}{c}\text { Uniformity - VD }= \\
\quad L \min / L \max \end{array}$ & $\begin{array}{l}\text { Uniformity - VI = } \\
\text { Lmin/Lrata-rata }\end{array}$ & $\begin{array}{r}\text { Batas ambang } \\
\text { silau - TJ...\% }\end{array}$ \\
\hline Bimasakti Eco 10 Watt 220 VAC Street Lighting & \multirow{4}{*}{2 s.d 5} & \multirow{4}{*}{0,5} & \multirow{4}{*}{1 s.d 4} & \multirow{4}{*}{0,1} & \multirow{4}{*}{0,1} & \multirow{4}{*}{0,4} & \multirow{4}{*}{0,5} & \multirow{4}{*}{20} \\
\hline Bimasakti Eco 20 Watt 220 VAC Street Lighting & & & & & & & & \\
\hline Bimasakti Eco 30 Watt 220 VAC Street Lighting & & & & & & & & \\
\hline Bimasakti Eco 40 Watt 220 VAC Street Lighting & & & & & & & & \\
\hline
\end{tabular}

Disebagian ruas jalan Depok Cilodong tepat disepanjang jalan Raya Haji Abdul Gani didapatkan jalan aspal tanpa trotoar, jadi penulis menganjurkan agar dibuat perancangan trotoar jalan 
untuk pedestrian sebagai tempat pemasangan lampu PJU agar lebih aman dan nyaman bagi pedestrian.

Dalam tabel 1, standar kualitas pencahayaan berdasarkan acuan Standar SNI 7391:2008. Dengan jenis jalan primer dan trotoar standar untuk tipe lampu Bimasakti Eco 10W, 20W, 30W, dan 40W, dengan tegangan $220 \mathrm{VAC}$ kuat pencahayaan jalan antara 2-5 Lux, lumen rata-rata jalan 0,5 $\mathrm{Cd} / \mathrm{m}^{2}$, sedangkan pencahayaan trotoar jalan antara 1-4 Lux, dengan lumen rata-rata $0,1 \mathrm{Cd} / \mathrm{m}^{2}$ dan batas ambang kesilauan $20 \%$, uniformity-VI 0,5 Lmin/Lrata-rata dan uniformity-gl sebesar 0,1 Emin/Emax.

Tabel 2. Data Spesifikasi Lampu Jalan dan Perancangan Jalan Lokal dan Trotoar

\begin{tabular}{|c|c|c|c|c|c|c|c|c|c|c|}
\hline \multicolumn{7}{|c|}{ Spesifikasi lampu jalan } & \multicolumn{4}{|c|}{ Rencana aplikasi jalan dan trotoar } \\
\hline Tipe lampu & $\begin{array}{l}\text { Daya } \\
\text { lampu } \\
\text { (watt) }\end{array}$ & $\begin{array}{l}\text { Efikasi lampu } \\
\text { (Lumen/watt) }\end{array}$ & $\begin{array}{c}\begin{array}{c}\text { Pencahayaan } \\
\text { (Luminaire - } \\
\text { Lux) }\end{array} \\
\end{array}$ & $\begin{array}{l}\text { Pencahayaan } \\
\text { (Lamp - Lux) }\end{array}$ & \begin{tabular}{|c|} 
Rekomendasi \\
pabrik tinggi \\
lampu dari jalan \\
(meter)
\end{tabular} & $\begin{array}{c}\text { Rekomendasi } \\
\text { pabrik jarak } \\
\text { antar tiang } \\
\text { (meter) }\end{array}$ & Jenis jalan & $\begin{array}{c}\text { Jenis trotoar } \\
\text { dan lebar } \\
\text { (meter) }\end{array}$ & $\begin{array}{l}\text { Lebar jalan } \\
\text { (meter) }\end{array}$ & $\begin{array}{c}\text { Rencana jarak } \\
\text { antar tiang } \\
\text { (meter) }\end{array}$ \\
\hline $\begin{array}{l}\text { Bimasakti Eco } 10 \text { Watt } 220 \text { VAC } \\
\text { Street Lighting }\end{array}$ & 11,9 & 95,4 & 1134,12 & 1134,2 & \multirow{4}{*}{ 7s.d 12} & \multirow{4}{*}{10 s.d 20} & \multirow{4}{*}{$\begin{array}{l}\text { Jalan lokal - } \\
\text { aspal (Depok - } \\
\text { Cilodong) }\end{array}$} & \multirow{4}{*}{$\mid \begin{array}{c}\text { Trotoar standar } \\
\text { pada } 2 \text { sisi } \\
\text { jalan, masing-2 } \\
\text { sisi } 0,5 \text { meter }\end{array}$} & \multirow{4}{*}{$\begin{array}{c}\text { Masing-masing } \\
\text { untuk } 5 \text { meter } \\
\text { dan } 6 \text { meter }\end{array}$} & \multirow{4}{*}{$\begin{array}{c}\text { Masing-masing } \\
10 \text { meter, } 15 \\
\text { meter, } 20 \text { meter }\end{array}$} \\
\hline $\begin{array}{l}\begin{array}{l}\text { Bimasakti Eco } 20 \text { Watt } 220 \text { VAC } \\
\text { Street Lighting }\end{array} \\
\end{array}$ & 21,3 & 86,7 & 1845,91 & 1845,9 & & & & & & \\
\hline $\begin{array}{l}\text { Bimasakti Eco } 30 \text { Watt } 220 \text { VAC } \\
\text { Street Lighting }\end{array}$ & 30,1 & 181,5 & 5468,03 & 5468,9 & & & & & & \\
\hline $\begin{array}{l}\text { Bimasakti Eco } 40 \text { Watt } 220 \text { VAC } \\
\text { Street Lighting }\end{array}$ & 38,9 & 178,2 & 6929,37 & 6929,8 & & & & & & \\
\hline
\end{tabular}

Untuk perancangan dan pemantauan jenis material jalan lokal aspal dan trotoar Depok Cilodong dengan lebar jalan masing-masing 5 meter dan 6 meter, untuk tipe lampu Bimasakti Eco 10W, 220 VAC street lighting, efikasi lampu 95,4 Lumen/Watt dengan pencahayaan lampu 1134,2 Lux, jenis trotoar standar dengan 2 sisi jalan, masing-masing sisi 0,5 meter, didapat jarak antar tiang masing-masing 10 meter, 15 meter, dan 20 meter dapat dilihat pada tabel 2.

\subsection{Rasio Kemerataan Pencahayaan (uniformity ratio)}

Rasio maksimum antara kemerataan pencahayaan maksimum dan minimum menurut lokasi penempatan tertentu adalah seperti yang ditentukan pada tabel 2. Pencahayaan pada ruas jalan dengan rasio kemerataan pencahayaan (uniformity ratio), pemilihan jenis dan kualitas lampu penerangan jalan serta penempatan lampu penerangan disesuaikan dengan lokasi penempatan, seperti di wilayah Depok Cilodong. Penempatan lampu ini dapat ditata dengan didasarkan nilai efisiensi, umur rencana, kekontrasan permukaan jalan dan objek dilapangan. Untuk wilayah pemukiman Cilodong, jalur lalulintas dengan rasio maksimum $6: 1$ dan jalur pejalan kaki $10: 1$.

\subsection{Penempatan Lampu Penerangan Jalan}

Dalam menempatkan lampu penerangan jalan umum harus ditata sedemikian rupa agar memberikan keselamatan dan keamanan bagi pengguna jalan, baik itu pencahayaan disekitar area tikungan atau persimpangan jalan, dibandingkan bagian jalan yang lurus. Pada sistem penataan parsial, lampu penerangan jalan harus memberikan adaptasi yang baik bagi penglihatan si pengendara, sehingga efek kesilauan dan ketidaknyamanan penglihatan dapat dikurangi. Adapun peletakkan pemasangan lampu LPJU dapat ditunjukkan sesuai dengan gambar 5 berikut. 


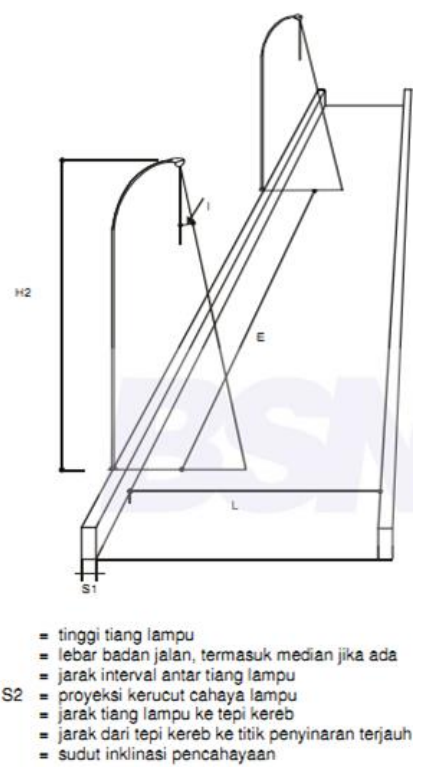

Gambar 5. Penempatan Lampu Penerangan [6]

Setelah penulis mendapatkan semua data-data yang didapat dari spesifikasi umum/teknis lampu jalan dan data jalan dilapangan, dan merancang penataan lampu penerangan dan lebar badan serta trotoar jalan, penulis menata letak lampu sesuai ukuran yang ada dilapangan. Kemudian datadata lampu jalan Bimasakti Eco 10W, 20W, 30W, dan 40W dan pengukuran lebar jalan tersebut diolah dan dirancang menggunakan metode tampilan aplikasi Dialux evo 8.2 seperti menurut gambar 5 berikut.

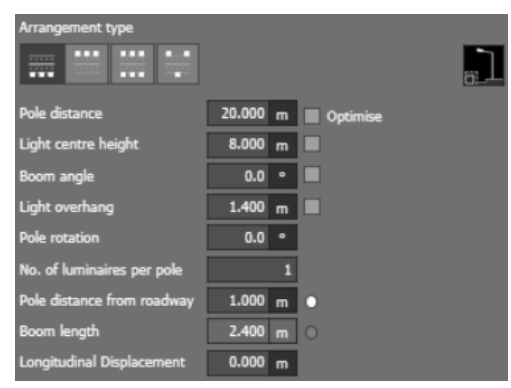

(a)

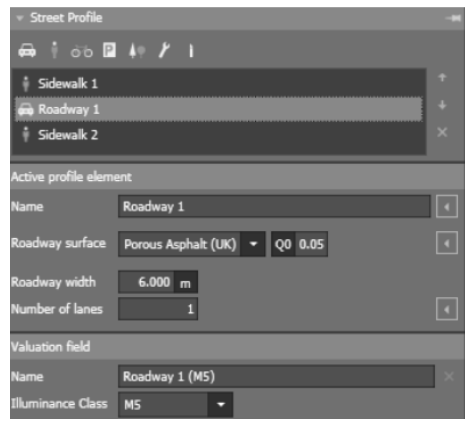

(b)

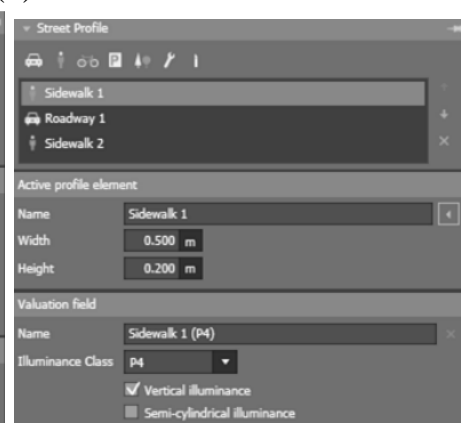

(c)

Gambar 6. Metode Tampilan Program DIALux evo 8.2 [11]

Untuk tipe model pemasangan lampu jalan yang dipakai dengan setting menggunakan program DIALux evo 8.2 dapat diperlihatkan pada gambar 7 berikut ini. 

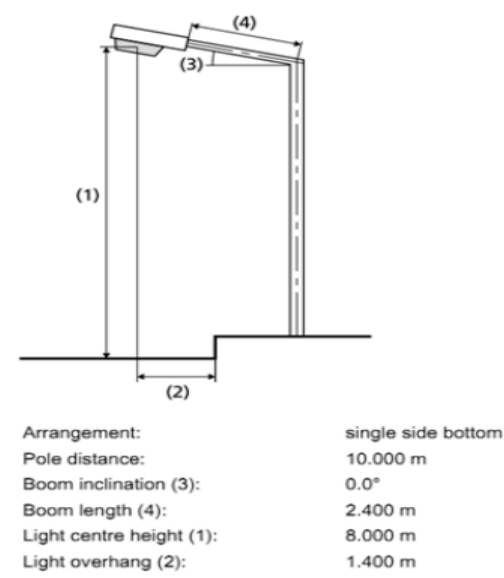

Gambar 7. Tipe Model Lampu Jalan Dengan Set Program DIALux evo 8.2 [6],[8],[9]

Dengan penulis memilih tipe lampu Bimasakti Eco dengan konsumsi daya 10W, lebar jalan 5 meter, maka jarak antar tiang yang diberikan 10 meter dengan kualitas pencahayaan 3,86 Lux, kualitas pencahayaan untuk trotoar 1 adalah 3,69 Lux, dan trotoar 2 sebesar 4,12 Lux, untuk uniformity pencahayaan jalan UI 0,88 Lmin/Lmax, sedangkan UO 0,88 Lmin/Lrata-rata, seperti yang ditunjukkan pada tabel 3 dan tabel 4 berikut ini.

Tabel 3. Tipe Lampu Jalan dengan Hasil Dialux evo 8.2

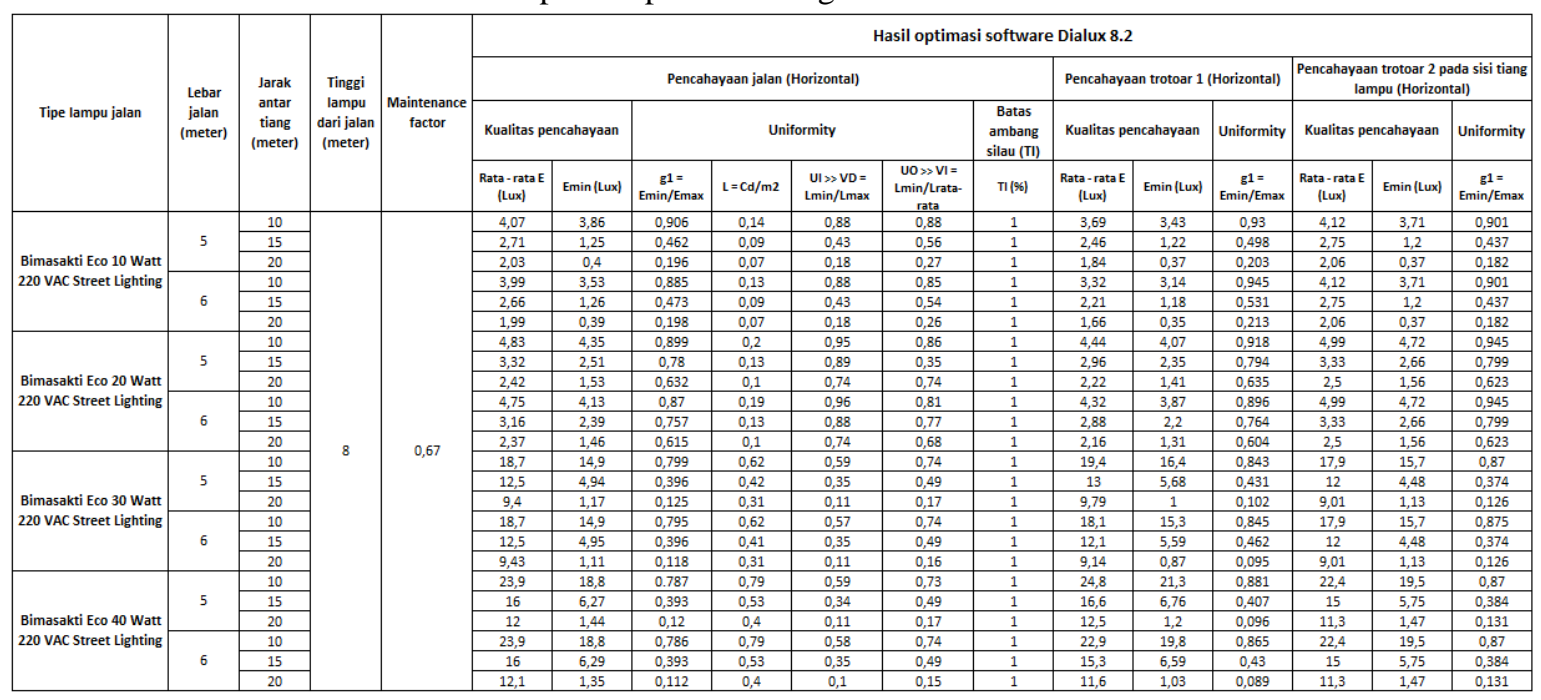

Tabel 4. Optimasi Setting Perencanaan Lampu Jalan Dengan Dialux evo 8.2

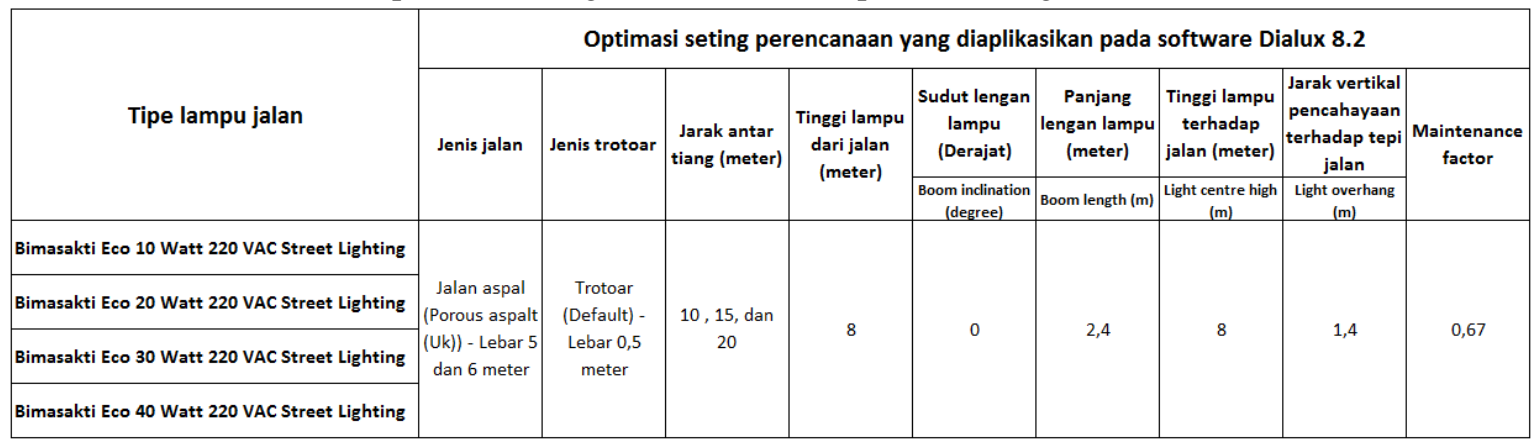




\section{Energi dan Kelistrikan: Jurnal Ilmiah}

Vol. 12, No. 2, Juli - Desember 2020, P-ISSN 1979-0783, E-ISSN 2655-5042

https://doi.org/10.33322/energi.v12i2.982

Sehingga optimasi setting perencanaan lampu jalan Bimasakti Eco 10W, 20W, 30W, 40W dengan lebar jalan aspal 5 meter dan 6 meter untuk tinggi lampu 8 meter dan lebar trotoar 0,5 meter jarak vertikal pencahayaan terhadap tepi jalan 1,4 meter, dengan maintenance factor 0,67 pada tabel4.

Analisa penggunaan software Dialux 8.2 yang diterapkan pada 4 buah jenis lampu Bimasakti tipe Eco (10W, 20W) dan Bimasakti-S tipe Series (30W, 40W) ini dimaksudkan untuk mendapatkan hasil perencanaan pencahayaan lampu jalan yang sesuai dengan standar SNI 7391-2008, efektifitas jumlah lampu jalan (kuantitas) yang dipasang, serta biaya pemasangan, dapat dilihat pada tabel 5 , didapat berdasarkan tipe lampu 10 Watt, lebar jalan 5 meter, jarak antar tiang 10 meter, uniformity trotoar 1 dan 2, ambang silau jalan pemberian nilai 1, dengan Analisa skor maksimal 6 lampu,Sedangkan lampu 20 Watt, dengan lebar jalan dan jarak antar tiang yang sama, uniformity trotoar 1 dan 2, ambang silau jalan pemberian nilai 1, dan analisa skor hanya maksimal 5 lampu,

Tabel 5. Analisa Hasil Perbandingan Perancangan Lampu Bimasakti Eco (10W, 20W) Berdasarkan Pemberian Skore Dengan Dialux evo 8.2 dan Standar SNI 7391-2008

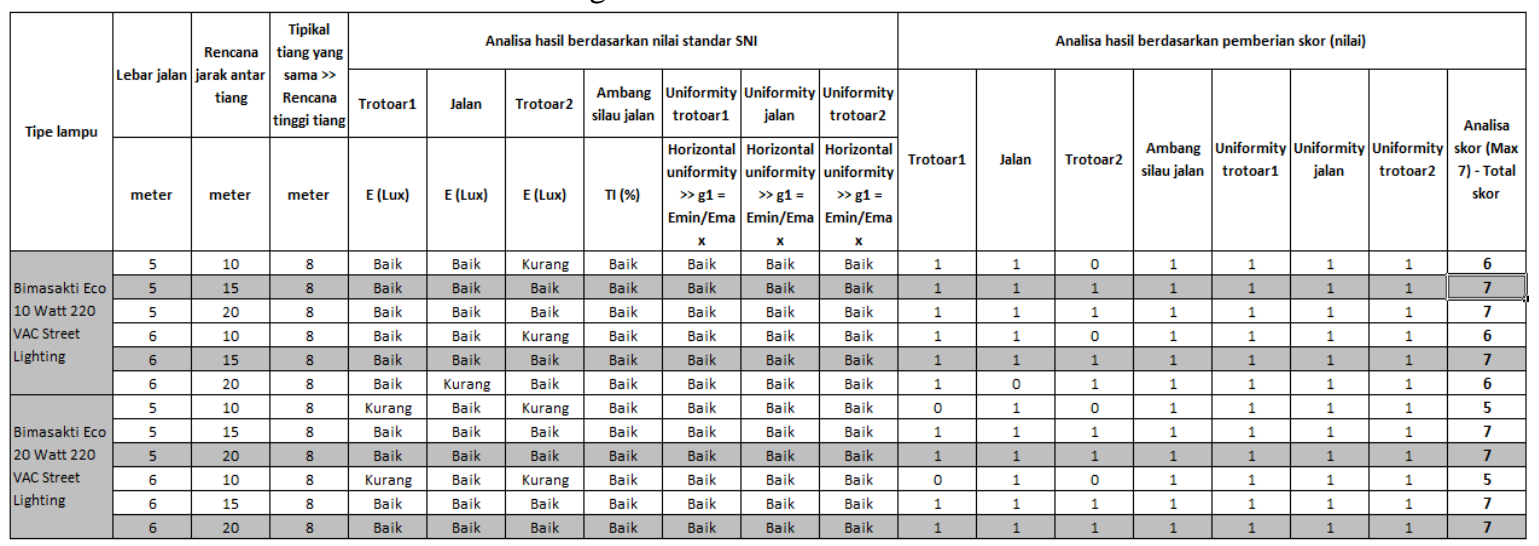

Kriteria terhadap kesesuaian standar SNI 7391-2008 yang diambil adalah:

1. Pencahayaan rata-rata untuk trotoar dan jalan-E (Lux)

2. Nilai ambang silau jalan-TI (\%)

3. Nilai kemerataan cahaya (uniformity) pada trotoar dan jalan-g1 = Emin/Emax

Untuk kriteria jumlah lampu yang akan dipasang beserta biaya pasang adalah dengan mempertimbangkan biaya yang muncul, dimana bila untuk jarak jalan yang tidak jauh maka lebih efisien menggunakan lampu yang watt-nya lebih kecil karena pengadaan dan dengan jumlah lampu yang relatif juga sedikit tersebut maka biaya pasangnya juga tidak besar. Akan tetapi untuk jarak jalan yang panjang maka bisa lebih efisien menggunakan lampu dengan watt besar, karena jumlah pengadaan akan lebih sedikit karena jarak antar tiang yang relatif jauh, sehingga mempengaruhi juga biaya pasang, karena jumlah yang dipasang relatif sedikit dibandingkan dengan bila dipasang lampu dengan watt kecil dengan jarak antar tiang yang dekat.

Dari kriteria tersebut dibandingkan dengan standar standar SNI 7391-2008 diberikan predikat "Baik" apabila nilainya masuk pada batasan standar. Sehingga dari keempat lampu led Bimasakti Eco tersebut, yang memenuhi semua kriteria tersebut (diatas) adalah Bimasakti Eco 10W 220VAC dan Bimasakti Eco 20W 220VAC. Berikut grafik dari analisa efektifitas pemasangan lampu jalan yang akan dipasang, dapat diperlihatkan pada grafik gambar 7 berikut. 
Analisa Efektifitas Pemasangan Lampu Jalan Terhadap Standar SNI 7931-2008

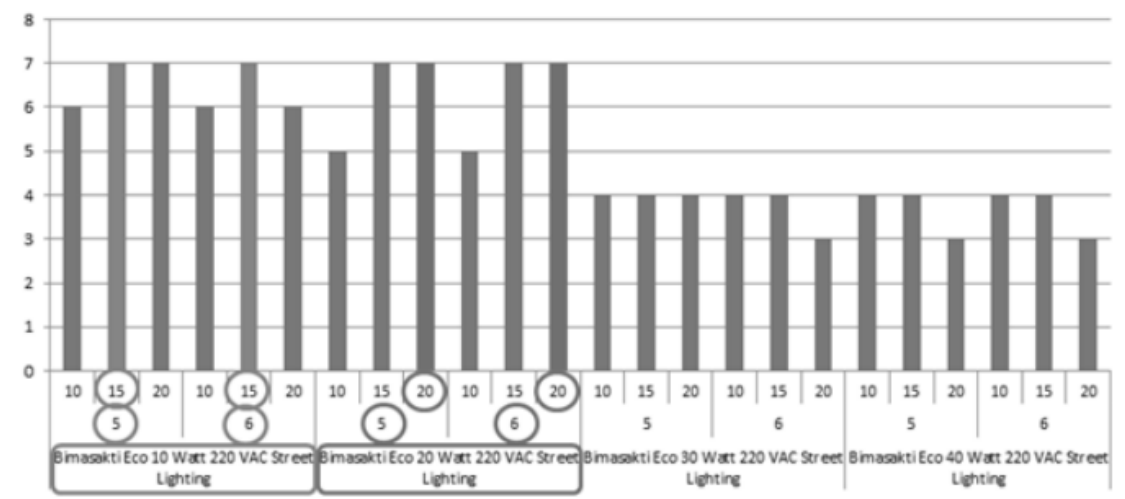

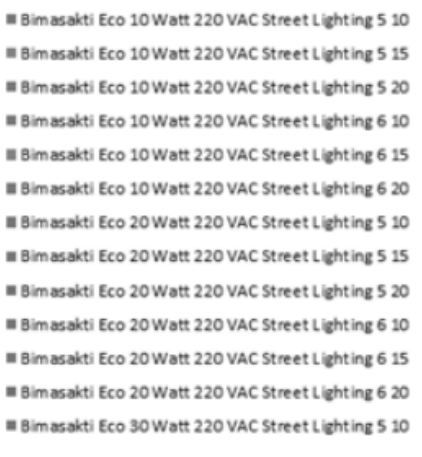

Gambar 8. Grafik Hasil Analisa Efektifitas Pemasangan Lampu Bimasakti ECO

(10W, 20W, 30W, 40W) Terhadap Standar SNI 7391-2008

Sedangkan berdasar analisa efektifitas pemasangan lampu 30 Watt dan 40 Watt, dengan lebar jalan dan jarak antar tiang yang sama, uniformity trotoar 1 dan 2 , dan ambang silau jalan sama dengan nilai 1, dengan analisa skor hanya maksimal 4 lampu saja. Sehingga bila dibandingkan dengan standar SNI 7391-2008, lampu yang digunakan maksimal 5 lampu.

\section{KESIMPULAN DAN SARAN}

Dari hasil analisa di atas, efektifitas Pemasangan Lampu Bimasakti ECO (10W, 20W, 30W, 40W) dengan perbandingan standar SNI 7391-2008, maka disimpulkan sebagai berikut : Dengan mempertimbangkan segi banyaknya pengadaan yang memungkinkan timbulnya biaya (cost) yang tinggi, maka untuk panjang jalan yang jaraknya pendek bisa menggunakan lampu jalan Led Bimasakti ECO 10W, $10 \mathrm{VAC}$, dimana dipasang dengan tinggi tiang 8 meter dengan jarak antar tiang 15 meter.

Untuk pemasangan lampu jalan Bimasakti untuk panjang jalan yang jaraknya jauh, bisa menggunakan lampu jalan Led Bimasakti ECO 20W, 10 VAC, dimana dipasang dengan tinggi tiang 8 meter dan jarak antar tiang 20 meter. Sehingga dengan kriteria pemilihan tersebut akan mampu menghasilkan pemasangan lampu jalan dengan tingkat pencahayaan yang sudah sesuai dengan SNI 7391-2008 dan dengan mempertimbangkan kuantitas pengadaan material serta titik pasang yang juga bisa berdampak pada pembiayaan terhadap jasa pemasangan.

Dalam perancangan dan pemasangannya sebaiknya disarankan sesuai dengan kondisi dan luas area badan jalan, sehingga jarak antar tiang dan tinggi lampu tidak memerlukan banyak titik pasang lampu, sehingga disesuaikan standar tingkat pencahayaan yang ada.

\section{UCAPAN TERIMAKASIH}

Akhir kata, Penulis menyampaikan ucapan terima kasih khusus kepada:

1. Bapak Ir. Syamsul Bahri beserta staf Kantor Dinas DKI Bina Marga Divisi PJU

2. Bapak Prof. DR. Ir. Iwa Garniwa M.K, MT, selaku Rektor Institut Teknolgi PLN

3. Bapak Indrianto, selaku Kepala LPPM Institut Teknologi PLN, beserta Dekan Fakultas Ketenagalistrikan dan Energi Terbarukan Institut Teknologi PLN dan Tim yang telah memberi dukungan dan membantu terlaksananya penelitian dan atau penulisan ini dengan baik dan lancar. 


\section{Energi dan Kelistrikan: Jurnal Ilmiah}

Vol. 12, No. 2, Juli - Desember 2020, P-ISSN 1979-0783, E-ISSN 2655-5042

https://doi.org/10.33322/energi.v12i2.982

\section{DAFTAR PUSTAKA}

[1] Endah Setyaningsih, Jeanny Pragantha, "Analisis Pencahayaan Malam Hari Terowongan Pasar Rebo Jakarta Timur", Jurnal Tesla Vol.19, No.1. Jurnal Tesla Teknik Elektro Universitas Tarumanagara, Jakarta Maret 2017.

[2] Endah Setyaningsih, Jeanny Pragantha, Lydwina Wardhani, "Tunnel Lighting For Vehicles In DKI Jakarta", 17 FSTPT International Sympocium, Jember 23 Agustus 2014.

[3] Endah Setyaningsih, Jeanny Pragantha,Rizki A. Mangkuto," "Simulasi Pencahayaan Terowongan Tomang Siang Hari Menggunakan Lampu LED", Jurnal Tesla Vol.20, No.1. Jurnal Tesla Teknik Elektro, Universitas Tarumanagara, Jakarta Maret 2018.

[4] Fabio Leccese,, "Remote Control System of High Efficiency and Intelligent Street Lighting Using a Zigbee Network of Devices and Sensors," IEEE Transactions on Power Delivery, Vol. 28 No.1, January, pp. 21-28, 2013.

[5] Nurrika, "Perencanaan Kebutuhan Aset Penerangan Jalan Umum (PJU) Pada Ruas Jalan Tangkubanperahu-Jalan Cagak di Kabupaten Subang,” J.Politeknik Negeri Bandung, 2017.

[6] Harry Sudibyo S, Amelinda Arum, Gunawan Wibisono, "Rancang Bangun Sistem Lampu Jalan Pintar Nirkabel Berbasis Teknologi Zigbee", Jurnal Tesla Vol.17, No.1, Jurnal Tesla Teknik Elektro Universitas Tarumanagara, Jakarta, Maret 2015.

[7] H. Iskandar Rusiana and N. Heryana, "Analisis Harmonik Lampu Penerangan Jalan Umum Berbasis LED Dengan Tegangan Bervariasi Dan Daya Konstan,” Pros. Semin. Ilm. Nasional, Pascasarj. Univ. Pamulang, 2017.

[8] Ilyas Achmad S, Bonar Sirait, Ir., M.Sc, Purwoharjono, DR, "Rancang Bangun Penataan Lampu Penerangan Jalan Umum Kota Sintang”, Jurnal Fakultas Teknik Elektro Universitas Tanjungpura, 2015.

[9] L. Danis and T. Surya, "Perbandingan Teknis dan Ekonomis Penggunaan Penerangan Jalan Umum Solar Cell Dengan Penerangan Jalan Umum Konvensional," Jurnal Teknik Elektro Universitas Sumatera Utara, 2014.

[10] Pedoman Bahan Konstruksi Bangunan dan Rekayasa Sipil, "Perencanaan Teknis Fasilitas Pejalan Kaki", Kementerian PUPR, SK PUPR Nomor: 02/SE/M/2018, Tanggal: 26 Februari 2018, 2018.

[11] S. S. Harry, A. Amelinda, and G. Wibisono, "Rancang Bangun Sistem Lampu Jalan Pintar Nirkabel Berbasis Teknologi Zigbee,” J. Tesla Tek. Elektro Univ. Tarumanagara, vol. 17, p. $1,2015$.

[12] Ramadhan Harisman, dkk, Muhammad Handry Imansyah, Philip Munzinger dkk, "Desain Mekanisme Pembiayaan Lampu Penerangan Jalan Umum Hemat Energi LED Untuk Pemerintah Daerah", Kementerian Keuangan Republik Indonesia, Badan Kebijakan Fiskal, Pusat Kebijakan Pembiayaan Perubahan Iklim dan Multilateral, Jakarta, Melalui proyek: Policy, Advice for Environtment and Climate Change, 2015.

[13] R. L. Team, Roadway Lighting Design Guide. Standard Engineering Practice section 4, 2017.

[14] Dialux, Handbook Dialux evo Manual Board Version 8.2 3D Lighting Projects. 2016.

[15] S. Gunawan, "Studi Penggunaan Lampu LED Untuk Efisiensi Pada Pencahayaan Jalan Layang RE. Martadinata,” E-Journal Kaji. Tek. Elektro Univ. 17 Agustus 1945, vol. 1, 2017. 